\title{
Da Legitimidade das Súmulas Vinculantes
}

\author{
Gustavo Callefi Hirata* \\ Silvio Alexandre Fazolli**
}

\begin{abstract}
1 Introdução. 2 Dos motivos da instituição das súmulas vinculantes. 3 Das críticas às súmulas vinculantes. 3.1 Do princípio da separação dos poderes. 3.1.1 Da "natureza legislativa" das súmulas vinculantes. 3.1.2 Da inacumulabilidade das funções jurisdicional e legislativa no Estado de Direito. 3.2 Da uniformidade jurisprudencial pretendida. 3.3 Do princípio da independência judicial. 4 Da legitimidade (possível) das súmulas vinculantes. 4.1 Da não coincidência entre índole política (stricto sensu) e função legislativa. 4.2 Da hermenêutica (necessária) dos verbetes sumulares. 4.3 Do controle de constitucionalidade dos enunciados sumulares. 5 Considerações finais. Referências.
\end{abstract}

\section{RESUMO}

Este artigo trata da compatibilidade do instituto das súmulas vinculantes com os princípios da separação dos poderes e da independência judicial, bem como analisa a forma como sua metodologia de aplicação impacta os postulados de igualdade material e de justiça. O debate em torno da legitimidade desse instituto é necessário, tendo em vista o caráter marcadamente pragmático que orientou sua criação por meio da Emenda Constitucional n. ${ }^{\circ} 45 / 2004$. Com a constatação inicial da "natureza legislativa" das súmulas vinculantes, abordam-se os impasses que seus propósitos originais geram no ordenamento jurídico brasileiro, haja vista os princípios e os postulados antes informados. No entanto, esta pesquisa se propõe a analisar as possíveis soluções aos problemas apontados. Assim, a hipótese aqui defendida é de que as súmulas vinculantes podem, sim, se revelar legítimas, ainda que, para tanto, alguns de seus termos iniciais tenham de ser revistos, e outros grandes debates tenham de ser enfrentados.

Palavras-chave: Súmula Vinculante. Legitimidade. Ordenamento jurídico brasileiro.

\section{INTRODUÇÃO}

O instituto das súmulas vinculantes encontrou ampla aceitação na comunidade jurídica brasileira, muito porque ele foi um dos instrumentos aclamados como solução à "crise do Judiciário", que, embora tenha outras nuances, ressalta no volume de processos que demoram

* Graduado em Direito pela Universidade Estadual de Maringá - UEM. Aluno Especial da disciplina 'A Empresa Contemporânea e o Regime Jurídico Brasileiro' do Mestrado em Direito Negocial da Universidade Estadual de Londrina - UEL. E-mail: <gchirata@gmail.com>.

** Doutor em Direito Econômico e Socioambiental pela Pontifícia Universidade Católica do Paraná - PUCPR. Mestre em Tutela dos Direitos Supra-Individuais pela Universidade Estadual de Maringá - UEM. Professor da Universidade Estadual de Maringá-UEM (professor efetivo) e da Pontifícia Universidade Católica do Paraná - PUCPR (professor adjunto).E-mail: <fazolli@gmail.com>. 
longos anos no Judiciário até receberem uma decisão definitiva. Por isso, frente ao caráter pragmático que marcou a instituição das súmulas de jurisprudência com efeito vinculante, é imperativa a análise de sua legitimidade no ordenamento jurídico brasileiro.

Legitimidade não se confunde apenas com legalidade ou constitucionalidade. $\mathrm{Na}$ verdade, estas são redutíveis àquela, já que legitimidade implica uma análise da compatibilidade de um ente para além do plano legal ou constitucional - ou seja, para além dos textos normativos - a fim de se averiguar sua harmonia com o todo jurídico.

No caso, as súmulas vinculantes serão confrontadas com princípios e valores que informam a ordem jurídica brasileira, especialmente, o republicanismo e o Estado de Direito, cujos pressupostos não se encontram todos explícitos no texto constitucional - há, então, o motivo de uma análise de legitimidade, já que a constitucionalidade (ao menos formal) desse instituto não se põe em dúvida.

Com esse escopo, será abordado neste trabalho: primeiro, os motivos que levaram à instituição das súmulas vinculantes; em seguida, os óbices que elas causam a algumas das ideias-base do ordenamento jurídico brasileiro; e, por fim, os caminhos que permitem a superação da falta de legitimidade do instituto, ainda que isso implique sua "desnaturação" para seus termos originais.

\section{DOS MOTIVOS DA INSTITUIÇÃO DAS SÚMULAS VINCULANTES}

No Brasil, muito se fala em "crise do Judiciário (da Justiça)", ou apenas em "crise de legitimidade" do Judiciário, cuja principal causa - segundo dizem - é o grande volume de processos nos Fóruns e Tribunais do país (TOFFOLI, 2013, p. 41-55).

Com base, sobretudo, nesse diagnóstico, foi aprovada a Emenda Constitucional n. ${ }^{\circ} 45$, de 2004, conhecida como "Reforma do Poder Judiciário". Ela, além de acrescer o direito fundamental à razoável duração do processo, encartou algumas medidas tendentes a promover a tão sonhada celeridade processual, dentre as quais se encontram as súmulas vinculantes.

Ocorre que, no mote principal das súmulas vinculantes - qual seja, a aceleração da solução definitiva dos conflitos judiciais -, estava o fim precípuo do instituto: desafogar os Tribunais de cúpula, mais precisamente, o Supremo Tribunal Federal (embora aqui não se negue que existe certa relação entre tais propósitos quando se colocam em pauta os processos que chegam aos Tribunais Superiores e lá aguardam, até mesmo anos, para serem analisados).

Nesse sentir, a doutrina também aponta que a própria estrutura do art. 103-A da CF denuncia esse fim primeiro das súmulas vinculantes. Nas palavras de Osmar Côrtes, "A simples leitura do $\S 1$. $^{\circ}$ deixa clara a natural intenção de evitar o acúmulo de processos, muitas vezes desnecessários, em trâmite perante o STF." (CÔRTES, 2008, p. 192). No mesmo sentido, Alexandre Sormani e Nelson Santander reiteram que o propósito "confesso" do instituto "[...] é a diminuição do volume de processos que tramitam pelos órgãos judiciários 
de cúpula [...]" (SORMANI; SANTANDER, 2009, p. 155); propósito esse que, aliás, foi explicitamente admitido pelo idealizador da "Súmula da Jurisprudência do Supremo Tribunal Federal”, o ex-Ministro Victor Nunes Leal, à época em que ainda só se editavam súmulas "simples" (persuasivas) (LEAL, 1981, p. 15).

Além do alegado propósito de celeridade processual (rectius, desafogamento dos Tribunais Superiores), também foram levantadas as bandeiras da segurança jurídica e da isonomia entre as partes em prol do instituto em mesa, sob o argumento de que é inaceitável que sejam proferidas decisões díspares para casos idênticos.

Nesse sentido, Victor Nunes Leal já anunciava, em 1964, os benefícios da "Súmula" para se evitar a "lotérica judiciária" existente à época, sobretudo por causa de maiorias ocasionais nos Tribunais. De acordo com ele:

Do mesmo modo, razões práticas, inspiradas no princípio da igualdade, aconselham que a jurisprudência tenha relativa estabilidade. Os pleitos iguais, dentre de um mesmo contexto social e histórico, não devem ter soluções diferentes. A opinião leiga não compreende a contrariedade dos julgados, nem o comércio jurídico a tolera, pelo seu natural anseio de segurança (LEAL, 1964, p. 455).

Outrossim, Osmar Côrtes aponta a necessidade de se assegurar a previsibilidade das decisões (ou seja, a segurança jurídica) para se viabilizar a organização social e a convivência pacífica em seu seio (CÔRTES, 2008), ao passo que Rodolfo de Camargo Mancuso ressalta o aspecto econômico que a segurança jurídica ostenta quando se trata de investimentos internacionais, tendo em vista que os investidores também buscam a estabilidade da jurisprudência para o desenvolvimento de seus negócios. Por isso, para ele, a certeza das decisões teria deixado de ser mero "capricho interno" para se tornar imperativo nesta fase do capitalismo globalizado (MANCUSO, 2013, p. 40).

Diante de tais argumentos, houve grande adesão dos juristas nacionais às promessas das súmulas vinculantes. Contudo, também houve grande oposição a esse instituto, cujas razões, embora rejeitadas, principalmente por razões práticas, merecem ainda hoje a devida consideração, especialmente porque se observa no Brasil uma "subserviência" ao entendimento dos Tribunais Superiores, sobretudo, às súmulas de jurisprudência.

\section{DAS CRÍTICAS ÀS SÚMULAS VINCULANTES}

Apesar da observância quase cega às súmulas dos Tribunais Superiores, a crítica às súmulas vinculantes também se faz necessária, haja vista os grandes poderes que elas conferem ao Supremo Tribunal Federal. Além disso, reclama tal postura o fato de os assentos portugueses - instituto muito próximo às súmulas em debate ${ }^{1}$ - terem sido declarados inconstitucionais em Portugal - mais precisamente, o artigo $2^{\circ}$ do Código Civil português, de 1966, na parte em que atribuía "força obrigatória geral" aos assentos, foi declarado inválido em face da Constituição da República Portuguesa de 1976. 
Neste artigo, a análise da legitimidade das súmulas vinculantes cingir-se-á à discussão dos problemas suscitados frente ao princípio da separação dos poderes, à unidade do Direito (uniformidade jurisprudencial) pretendida e ao princípio da independência judicial - os quais se entendem de maior relevo para a aferição da legitimidade do instituto -, não se olvidando que existem outros aspectos que exigem reflexão, os quais, no entanto, não serão objeto deste estudo em razão de seu corte temático.

\subsection{DO PRINCÍPIO DA SEPARAÇÃO DOS PODERES}

Como indicado, há forte proximidade entre os assentos portugueses e as súmulas vinculantes, sobretudo porque se aponta como principal característica em comum a natureza de "prescrição legislativa" de ambos. Por óbvio, a atribuição de natureza de lei a tais institutos - que eram/são emitidos por Tribunais - suscita de pronto um impasse com o "princípio da separação dos poderes", consagrado no art. $2^{\circ}$ e tornado cláusula pétrea no art. $60, \S 4^{\circ}$, inciso III, ambos da Constituição da República Federativa do Brasil.

Porém, antes de se abordar propriamente a existência (ou não) de ofensa ao princípio em debate, cumpre explicitar os motivos que levam à conclusão da "natureza legislativa" das súmulas vinculantes.

\subsubsection{Da "Natureza Legislativa" das Súmulas Vinculantes}

A constatação da natureza jurídica (qualificação dogmático-jurídica) das súmulas vinculantes exige a própria análise de seu estatuto jurídico, o qual, analiticamente, compreende sua estrutura jurídica, sua intencionalidade e sua eficácia normativa.

Quanto à estrutura jurídica, as súmulas vinculantes se revelam como prescrições normativas. Ora, uma prescrição é um imperativo, um comando imposto por uma autoridade investida de poder para tanto. No caso, as súmulas com efeito vinculante tratam efetivamente disso, na medida em que são editadas por uma autoridade com competência constitucionalmente deferida, o Supremo Tribunal Federal, e revestidas de obrigatoriedade (ou "efeito vinculante").

Por sua vez, norma jurídica pode ser entendida como uma proposição cujo enunciado é abstratamente formulado para fins de uma aplicação genérica. Com efeito, as súmulas vinculantes se materializam em enunciados abstratos - vale dizer que elas se revelam por meio de proposições que se autonomizam, formal e normativamente, dos acórdãos que ensejaram sua edição -, para servirem como critério normativo a qualquer caso jurídico futuro que verse sobre a mesma matéria; então, extrai-se justamente a generalidade de sua aplicação (NEVES, 2014). ${ }^{2}$

Constatado isso, não se mostra correta a alegação de que as súmulas vinculantes mantenham o status jurisprudencial dos acórdãos que as embasaram, tendo em vista que a normatividade dos enunciados sumulares se desvincula da carga normativa das "reiteradas decisões" que autorizaram sua edição. Em outros termos, uma súmula vinculante não é 
aplicada porque os casos que a ensejaram são impositivos sobre as partes das respectivas causas julgadas (os efeitos da coisa julgada se encerram ali, nesses mesmos processos), mas sim porque ela própria é obrigatória (ABBOUD, 2008).

Em torno da teleologia, as súmulas vinculantes também ostentam a finalidade própria da legalidade, qual seja, a garantia da segurança e da igualdade jurídicas (NEVES, 2014). Como visto, as súmulas vinculantes se destinam justamente a salvaguardar tais valores jurídicos, tanto que eles foram amplamente utilizados como argumento para a aprovação do instituto na $\mathrm{EC} \mathrm{n}^{\circ} 45 / 04$.

No tocante à eficácia jurídica, ressalta a pretensão de vinculação universal do instituto, até porque seria ilógico intencionar abstração e generalidade, com o fito de preservar a segurança e a igualdade jurídicas, sem que todos fossem obrigados ao cumprimento dos enunciados sumulares. Em suma, seria inócuo esse instituto - vale dizer que ele não cumpriria sua finalidade - caso fosse desprovido de força universalmente vinculante.

Por isso, decorre desse estatuto jurídico o próprio reconhecimento das súmulas vinculantes como fontes formais do direito, ${ }^{3}$ na medida que a força vinculante das súmulas em estudo não provém da lei a que se refiram, mas sim de si próprias, como enunciados formal e autonomamente vinculantes.

Ademais, a previsão do art. $5^{\circ}$ da Lei $n^{\circ} 11.417 / 06^{4}$ não infirma a autônoma obrigatoriedade das súmulas vinculantes, a exemplo do que ocorre com as leis interpretativas. Estas, embora se refiram a outra lei, preservam sua autonomia em relação à lei interpretada - ou seja, não é o fato de seu teor ser integralmente remetido a outro diploma legal que retira da lei interpretativa força obrigatória própria.

Diante do exposto, não é temerário afirmar que as súmulas vinculantes ostentam natureza de "disposição legislativa", até porque elas se mostram compatíveis com o próprio conceito de "lei", a que se pode atribuir um sentido formal e outro material.

No sentido formal, a noção de lei é atrelada ao órgão responsável por sua edição, o qual, porém, não precisa ser o titular da função legislativa, mas sim qualquer órgão que detenha competência constitucional para tanto. ${ }^{6}$ Enquanto isso, no sentido material, a lei é qualificada como a norma jurídica que possui direta e universal incidência no ordenamento jurídico (NEVES, 2014).

Isso posto, a constatação da "natureza legislativa" das súmulas vinculantes se mantém ao menos no sentido material (pois, de fato, tais súmulas atingem direta e universalmente seus destinatários, ainda que se insista na nota político-constitucional para se conceituar "lei", ou seja, ainda que se afirme que lei é apenas a norma editada pelo Poder Legislativo). ${ }^{7}$

\subsubsection{Da Inacumulabilidade das Funções Jurisdicional e Legislativa no Estado de Direito}

Constatada a natureza de "disposições legislativas", resta, então, averiguar se as súmulas vinculantes ofendem o princípio da separação dos poderes. Para responder a 
essa pergunta, será imprescindível saber antes se a função legislativa é exclusiva do Poder Legislativo e, caso não, se essa função pode ser cometida ao Poder Judiciário, tendo em vista certa concepção do Estado de Direito - na qual a Judicatura é vista como órgão de limitação dos Poderes políticos.

De início, importa anotar que a "função legislativa" não se confunde com o "Poder Legislativo". Enquanto este é tratado no plano jurídico-constitucional em termos do órgão legitimado para representar, de forma especial, o "povo soberano" - traduzindo, portanto, um conceito com notável carga política -, aquela apenas expressa uma forma de prescrição normativa - revelando-se, portanto, um conceito dogmático e neutro (NEVES, 2014, p. 399-400).

Além disso, a própria Constituição da República Federativa do Brasil, desde sua promulgação, sempre atribuiu funções legislativas a autoridades não pertencentes ao Poder Legislativo, sendo emblemáticas, nesse sentido, as medidas provisórias (art. 62 da CF), cuja edição é atribuída ao chefe do Poder Executivo, bem como os regimentos internos dos tribunais pátrios, os quais são editados pelas respectivas cortes (art. 96, I, "a", da CF) (SORMANI; SANTANDER, 2009).

Por isso, não se confundem Poder Legislativo e função legislativa, sendo que aquele não pode ser conceituado meramente com base nesta. Segundo Castanheira Neves, o Poder Legislativo é antes distinguido por sua qualificação política, e, caso seu conceito se limitasse à função legislativa, seria conferida uma neutralidade inexistente a esse Poder, cujo tom político - vale dizer, a busca pela conformação político-social por meio da legislação - é sua característica definidora (NEVES, 2014). Demonstrado que esses conceitos não se confundem, resta saber se a função legislativa é compatível com a atividade jurisdicional.

O princípio da separação dos poderes deixou de ter o valor absoluto e o sentido político que possuía no Estado liberal (SORMANI; SANTANDER, 2009), para se revestir de um sentido de estruturação estatal, o qual se revela por meio da distribuição dos poderes de governo a certos titulares, entre os quais, embora ainda exista certa distinção, deve antes predominar "uma convergência integrante numa coordenação e repartição complementar de funções." (NEVES, 2014, p. 403-404).

Além do sentido estrutural, o princípio em mesa também pretende a limitação do poder (o "checks and balances") ${ }^{8}$. Para tanto, o impedimento de que todos os Poderes assumam funções legislativas se torna imperativo, pois, caso contrário, ocorreria uma total e indiscriminada politização que tornaria inócuos os limites jurídicos que são essenciais ao Estado de Direito.

Com isso em vista, o juízo jurídico não deveria encontrar seu critério nos "efeitos" da decisão judicial, mas sim nos "fundamentos" de validade normativa; validade essa que deve pautar-se na intencionalidade axiológica de uma comunidade - ou seja, na sua ordem jurídica - e não na eleição "partidária" de um ou de alguns desses valores comunitários. Ora, quando se volta ao fundamento, há a submissão do juízo a um "absoluto" - ou seja, aos limites e à própria intencionalidade do Direito -, ao passo que, ao se pautar nos efeitos, a decisão se conduz por um "relativo", expresso em termos de conveniência e oportunidade (NEVES, 2014, p. 443-445). 
Ora, o Direito deve ser uma ordem axiológico-material (e não finalística) da comunidade soberana, cujos valores mínimos sejam reconhecidos na dignidade humana e nos direitos fundamentais. Não se olvida que concorrem com essa intencionalidade axiológica (de validade) outras intenções específicas das demais ordens do sistema político, como as intenções ideológicas e partidárias recorrentemente encontradas na legislação, a qual é rotineiramente utilizada como critério normativo. No entanto, estas não devem preferir àquela, quando da solução do caso concreto, sob o risco de se perder o Direito como limite ao poder (NEVES, 2014).

Com a prevalência da intencionalidade ao Direito no juízo jurídico, a função jurisdicional acaba por superar as próprias intencionalidades parciais (políticas) das leis, ao submetê-las ao crivo de validade, que se fundamenta no todo axiológico comunitário. E, por afirmar os valores e os princípios universais da intenção comunitária, a função jurisdicional revela-se política, mas não no sentido que é próprio ao Legislativo. ${ }^{9}$

Diante do exposto, é possível concluir que, ao adentrar no jogo político dos demais Poderes, o Judiciário fragiliza sua condição de contrapoder - ou seja, o Direito não consegue mais ser limite ao político, o que implica a própria falência da concepção de um Estado de Direito que almeja a integração e harmonia da sociedade atual (eminentemente plural) por meio da ordem jurídica.

\subsection{DA UNIFORMIDADE JURISPRUDENCIAL PRETENDIDA}

A uniformidade jurisprudencial é um dos escopos primordiais das súmulas vinculantes, já que é por meio dela que se prometeram a igualdade e a segurança jurídicas, bem como a entrega mais célere da prestação jurisdicional definitiva.

Contudo, a uniformidade aqui debatida remonta àquela antiga pretensão de tornar a lei (no caso, a súmula vinculante) premissa da qual se extraiam logicamente as normas jurídicas aplicáveis aos casos concretos; pretensão essa que, no entanto, encontra óbices na própria forma problemática de ser do Direito, pois revelam-se verdadeiros construtores do Direito em razão da problematicidade que lhe é ínsita (NEVES, 2014, p. 624-625).

O racionalismo - que impregna essa lógica positivista-legalista - impulsiona à consideração de que existem critérios unívocos de normatividade para casos idênticos, cujos fatos relevantes, subsumidos a uma mesma norma jurídica, implicariam sempre uma mesma solução normativa, independentemente das nuances particulares desses casos (cuja identidade, por certo, não é absoluta).

Nesse sentido, as súmulas vinculantes intencionam acabar com as interpretações divergentes sobre determinada norma jurídica; divergência essa que não decorreria da consideração das particularidades dos casos concretos, mas sim da apreensão díspar sobre o sentido abstrato e predefinido da norma (MACHADO, 2005). Por isso, acreditava-se que tais súmulas poderiam fixar a única interpretação aceitável dos dispositivos legais - ou seja, uma interpretação que fosse mais consentânea com a vontade da lei ou do legislador -, para, 
assim, restarem asseguradas a igualdade e a segurança jurídicas.

Com isso, a unidade pretendida pelas súmulas vinculantes se revela formal, abstrata e pressuposta - vale dizer que o sistema jurídico é encarado como completo e fechado, de modo que todas as soluções jurídicas podem ser extraídas dele lógico-dedutivamente -, sendo que dessa concepção (de unidade formal-abstrata) decorre a crença na própria possibilidade de se determinar a priori os critérios jurídicos aplicáveis aos casos concretos, os quais, uma vez apreendidos, impunham ser cristalizados em um enunciado que também permitisse aplicação lógico-dedutiva (no caso, em uma súmula vinculante) (MACHADO, 2005).

Nesse cenário apriorístico, o juiz se limitaria a investigar a compatibilidade formal do caso sub judice ao sentido unívoco da norma, em termos de aferição da compatibilidade (subsunção) dos fatos juridicamente relevantes desse caso à norma jurídica considerada. Desse modo, todos os casos idênticos - ou seja, cujas situações fáticas fossem idênticas deveriam ter inexoravelmente a mesma solução jurídica, pois, subsumidas a uma mesma norma, garantem a igualdade entre os jurisdicionados - em (des) favor dos quais sempre seriam prolatadas decisões isonômicas - e a segurança jurídica - em razão da previsibilidade das soluções jurídicas (MACHADO, 2005).

Contudo, o método lógico-dedutivo pressuposto pelas súmulas vinculantes não se compatibiliza com a própria realidade do Direito, que, como dito, é problemática. Por isso, não é aceitável a determinação apriorística de critérios jurídicos, como se correspondesse às exigências do Direito a redução de todos os casos concretos a um denominador comum.

Não se nega que é possível encontrar esse mínimo comum, tanto que as leis são elaboradas a partir de uma análise em abstrato do conjunto de casos que pretendem regular. Porém, tomar esse nivelamento como regra de aplicação jurídica é o mesmo que ignorar os reclamos de justiça. Não é por outro motivo que apenas a igualdade em sentido formal é consagrada com as súmulas de jurisprudência com efeito vinculante do Supremo Tribunal Federal.

Com efeito, as exigências de igualdade estabelecidas pela Constituição Federal estão para além desse traço formal prometido pelas súmulas vinculantes. Não basta mais a igualdade de todos perante a lei - ou seja, que todos recebam o mesmo tratamento previsto em lei, independentemente das condições pessoais de cada um, pois o imperativo de justiça impele a realização da igualdade em seu sentido material - vale dizer que sejam conferidas as chances efetivamente iguais a todos (SARLET et al., 2013).

Por isso, a atividade jurisprudencial orientada pelo método lógico-dedutivo, que é pressuposto pelas súmulas vinculantes, obsta a concretização material da igualdade (e da justiça), tendo em vista que as particularidades dos casos são simplesmente desprezadas destacam-se, também, as diferenças entre os desiguais, que não são observadas pelo juiz que se mantém preso à lógica silogística.

Assim, é perceptível a incompatibilidade dessa unidade do Direito e da metodologia de aplicação pretendida originalmente por esse instituto com o ordenamento jurídico-constitucional brasileiro, em razão do desprezo daquelas para com os ideais de justiça e de igualdade (material) presentes na Constituição da República Federativa do Brasil. 


\subsection{DO PRINCÍPIO DA INDEPENDÊNCIA JUDICIAL}

O princípio da independência judicial (que é pressuposto tanto pelo Estado de Direito, como pelo princípio da separação dos poderes) pode ser visto a partir dos sentidos político e axiológico.

Em termos políticos, ele encontra sua acepção tradicional, a qual mantém estreita ligação com o legalismo moderno. Por essa perspectiva, o Judiciário seria obediente apenas à lei, mas em termos de ser um poder nulo e seus juízes, meras "bocas da lei".

Por seu turno, no sentido axiológico - o qual, afinal de contas, é o que interessa, tendo em vista a (teórica) superação do legalismo -, a independência exige a contribuição (de forma criadora) de todos os magistrados para a realização do ideal de justiça, tendo em vista que é ínsita à realização do Direito a existência de um mínimo de divergência jurisprudencial que permita o exsurgimento do máximo de caminhos possíveis a certo impasse jurídico (NEVES, 2014). ${ }^{10}$

Além disso, seria demais crer que alguns poucos magistrados - por mais notável que seja seu saber jurídico - consigam esgotar as possibilidades do Direito e, assim, sejam sempre capazes de encontrar soluções jurídicas justas, sendo muito mais crível que entre milhares de juízes se encontre um ponto de vista mais coerente com a intenção de realização do Direito.

Por isso, negar a responsabilidade de todos os magistrados pela concretização do Direito é, de certo modo, propiciar o retorno do Estado brasileiro a um sistema de cariz autoritário, como ocorreu à época da Revolução Francesa com a "cassação". Nesse período, os revolucionários almejavam a obediência à lei - que era confundida com o próprio Direito -, buscando protegê-la contra o arbítrio (rectius, poder criativo) dos juízes por meio do "Tribunal de Cassation".

No caso pátrio, é possível constatar a retomada dessa intenção que norteou originariamente a cassação caso se considere que as súmulas vinculantes procuram justamente proteger os cânones legais, ao intencionarem a apreensão do (suposto) sentido ínsito e unívoco da norma jurídica (lei); sentido esse que, aliás, não deve ser passível de "adaptação" pelo magistrado no caso concreto.

Apesar disso, é possível ver nesse instituto um instrumento de controle hierárquico ao estilo das diretivas do Supremo Tribunal da União das Repúblicas Socialistas Soviéticas, tendo em vista a proximidade de seus estatutos jurídicos. Em torno das diretivas, Castanheira Neves as descreve como

[...] instruções de caráter genérico, vinculantes para as jurisdições subordinadas, relativamente ao modo como estas deverão decidir concretamente, já determinando a norma jurídica que há-de ser aplicada em certos casos, já esclarecendo duvidosas questões interpretativas e fixando o sentido da lei, já mesmo prescrevendo o modo como especiais pontos de facto deverão ser apreciados (NEVES, 2014, p. 116).

Por isso, revela-se correta a crítica dirigida ao caráter autoritário das súmulas vinculantes, na medida em que elas realmente se revelam como "instruções hierárquicas dirigidas pelas instâncias extraordinárias às ordinárias”, ao mesmo tempo em que os tribunais superiores 
encarregados de sua edição assimilaram uma "função administrativo-burocrática" própria do Poder Executivo (MACHADO, 2005, p. 146).

Isso posto, conclui-se que o instituto em comento ofende o princípio da independência judicial, pois, além de as súmulas vinculantes ostentarem caráter autoritário - por restringirem a liberdade decisória dos juízes -, elas refutam a possibilidade de contribuição de todo o Judiciário para a consecução de um direito efetivamente justo, relegando essa tarefa a apenas um tribunal - o que retoma o problema do "autoritarismo" ínsito à sua índole original.

\section{DA LEGITIMIDADE (POSSÍVEL) DAS SÚMULAS VINCULANTES}

Em que pesem os óbices apontados, ainda é possível afirmar a legitimidade das súmulas vinculantes, mesmo que isso custe a alteração de alguns de seus pressupostos originais, até porque o instituto em mesa não padece da inconstitucionalidade (material) de que padeciam os correlatos assentos portugueses.

Com efeito, a Constituição do Brasil não possui nenhum dispositivo como o artigo 115, $\mathrm{n}^{\circ}$ 5, da Constituição da República Portuguesa, ${ }^{11}$ o qual, consagrando o "princípio da tipicidade dos actos legislativos", serviu de fundamento para o Tribunal Constitucional português declarar inconstitucional o artigo $2^{\circ}$ de seu Código Civil, que previa a "força obrigatória" dos assentos (cf. Acórdão n 810/93 de tal Tribunal Constitucional) (PORTUGAL, 1993).

Embora inexista um dispositivo como aquele, a doutrina reconhece, no art. 59 da Constituição Federal, a adoção do supracitado princípio. Nesse sentir, Clèmerson Merlin Clève chega ao ponto de afirmar que: "[...] apenas os atos elencados no art. 59 constituem-se em atos legislativos.” (CLÈVE, 1997, p. 4). Não bastasse isso, mais à frente, ele é ainda mais enfático ao afirmar que: "[...] possuem forma de lei aquelas espécies previstas no art. 59 da CF/1988, em numerus clausus (apenas aquelas, salvante a hipótese de recepção de espécies pretéritas com a mesma força) [...]" (CLÈVE, 1997, p. 5, grifo do autor). Todavia, não parece acertada essa conclusão.

O reconhecimento do princípio da tipicidade dos atos legislativos na Constituição Federal se mostra como uma decorrência necessária da própria noção de Estado de Direito. Ora, as leis (no sentido de uma prescrição, ou seja, de uma disposição obrigatória) não podem ser passíveis de criação por qualquer órgão, pois, além de imporem direitos e obrigações, elas revelam a adoção de intenções político-jurídicas da comunidade.

Destarte, não se podendo relegar as escolhas políticas ao arbítrio de qualquer um, mas sim aos órgãos constitucionalmente legitimados para a promoção do consenso da comunidade, é indispensável que os tipos de disposições legislativas sejam restringidos somente àquelas formas utilizadas por esses órgãos legítimos.

Por isso, o princípio da tipicidade das leis apenas exige a previsão constitucional do (novo tipo de) ato legislativo, como ocorreu com a inserção do art. 103-A na Constituição Federal. A propósito, descabida seria eventual alegação de que as súmulas vinculantes são 
inconstitucionais pelo simples fato de não estarem previstas no rol do art. 59 da $\mathrm{CF} / 88$. Esse é, afinal, um preciosismo que não se justifica.

Isso porque o rol do art. 59 da CF/88, embora taxativo, não é inextensível, pois tipicidade não significa algo estanque ou fechado, mas, sim, algo previsto - no caso, constitucionalmente previsto. Nesse sentido, também é a tipicidade na seara penal, na qual, embora se exija que o crime seja anteriormente previsto em lei para que seja punível, ainda assim se admite a criação de novos "tipos penais", ou seja, de novos crimes.

Com isso em vista, vale recordar que as normas jurídicas (regras e princípios) não estão confinadas nos dispositivos legais, motivo pelo qual é possível afirmar que o art. 59 da Constituição Federal não limita, nem esgota o princípio da tipicidade das leis (ÁVILA, 2011). Com efeito, Humberto Ávila elucida que o texto não se confunde com a norma, pois, enquanto aquele é o objeto de interpretação, esta é o resultado desse trabalho interpretativo. A par disso, ele ainda constata que há normas sem dispositivos, bem como normas que decorrem de diversos dispositivos, como é o caso do princípio da segurança jurídica (ÁVILA, 2011). ${ }^{12}$

Assim, é possível concluir que, embora evidencie o princípio da tipicidade dos atos legislativos, o art. 59 da $\mathrm{CF} / 88$ não reclama exclusividade, até porque decorre da própria abertura desse princípio a possibilidade de que existam outras formas de disposições legislativas no texto constitucional, independentemente de elas se encontrarem em referido rol.

Portanto, não padecendo do mesmo problema que os assentos portugueses - qual seja, a previsão exclusiva no plano infraconstitucional ${ }^{13}$-, é de se reconhecer a compatibilidade das súmulas vinculantes com a exigência constitucional de tipicidade dos atos legislativos, justamente por terem sido instituídas no ordenamento jurídico brasileiro a partir de uma emenda da Constituição Federal.

Tendo isso em vista, e considerando a constitucionalidade formal da Emenda Constitucional $n^{\circ} 45 / 2004$, resta saber de que forma podem ser superados os óbices de ordem material que surgiram a partir das configurações originais do instituto em debate.

\subsection{DA NÃO COINCIDÊNCIA ENTRE ÍNDOLE POLÍTICA (STRICTO SENSU) E FUNÇÃO LEGISLATIVA}

Como exposto, a noção de "separação dos poderes" não é mais absoluta, sendo, em vez disso, destinada à estruturação e ao bom funcionamento de um Estado a partir da distribuição dos poderes inerentes à sua soberania. Sem embargo, as funções estatais primordiais - quais sejam, legislar, julgar e administrar ainda são constitucionalmente conferidas a cada um dos Poderes concebidos por Montesquieu.

Também se disse que o exercício da função típica não impede que determinado Poder exerça funções que, majoritariamente, são de incumbência de outro. Em outros termos, nenhuma dessas funções é exclusiva do Poder titular, razão pela qual não se confundem, v. g., Poder Legislativo e função legislativa. Aliás, como visto, nenhum sequer serve como critério conceitual (exclusivo) do outro, até porque a nota primordial do Poder Legislativo 
é o caráter político (em sentido estrito), ao passo que a função legislativa, como conceito dogmático, é neutra. Por sinal, é essa neutralidade da competência de se editarem disposições legislativas que permite cogitar a superação ao óbice apontado.

Segundo Castanheira Neves, o sistema político-jurídico atual é marcado tanto pela legislação quanto pela jurisdição, ao contrário do sistema moderno-iluminista, no qual sobressaia com exclusividade o Legislador. No Estado contemporâneo, há dois polos: um político, que se realiza por meio da legislação, e outro jurisdicional, que se pauta na validade do Direito. Embora distintos, ambos devem buscar uma concorrência dialética, a fim de promoverem, em uma intenção de unidade totalizante, "[...] certos valores últimos, plurais mas convergentes - da dignidade pessoal e da solidariedade social, da liberdade e da justiça." (NEVES, 2014, p. 596-598).

Embora tais valores sejam plurais e, portanto, propícios ao desencadeamento de conflitos, existe na sociedade o desejo por uma resposta integrante, a qual só é alcançada em sua plenitude por meio do Direito. Ora, a política também se utiliza de tais valores, porém não em um contexto global, mas sim parcial. Ela se vale deles em medidas diversas, privilegiando mais um do que outro ou mesmo deixando algum para um momento posterior, provindo daí os conflitos. Por sua vez, o Direito, por meio da jurisdição, é a instância integradora da ordem axiológica da comunidade.

Por isso, a unidade não se pode realizar senão por meio da interação dialética entre as funções legislativa e jurisdicional, até porque o Legislativo deixou de ser o portador da "vontade geral", como o era na Modernidade, para se tornar mais um órgão legitimado pela comunidade soberana, mas do qual expressa apenas parte - em manifestações parciais - de seus valores, tendo como veículo primordial a lei (NEVES, 2014, p. 598-599).

Contudo, no cenário atual, em que a própria lei se tornou "instrumento de governo" (NEVES, 2014, p. 601) dos Poderes Legislativo e Executivo, seria difícil pensar em seu uso pelo Judiciário (por meio das súmulas vinculantes) sem que ela levasse consigo o caráter marcadamente político que carrega hodiernamente.

Por tal motivo, Castanheira Neves se posicionou contrário aos assentos portugueses (cujas críticas valem às súmulas vinculantes pela proximidade entre ambos os institutos), isto é, pela tão só possibilidade (real) de o Judiciário se desprender da intencionalidade a que deve servir com exclusividade, caso deferido a ele um instrumento normativo de natureza legislativa, jamais se deveria concedê-lo, até porque, além de a função jurisdicional já ser hoje fortemente conduzida pelos "critérios-efeitos" - ou seja, pela finalidade (o que é próprio da intenção política) - e não pelo "critério-fundamento", não haveria instância de controle dos assentos editados, já que expedidos pelos próprios Tribunais Supremos (NEVES, 2014, p. 610-611). ${ }^{14}$

Não obstante esse risco, as súmulas vinculantes podem se harmonizar com os princípios estruturais do Estado de Direito, mais especificamente, com a manutenção do Poder Judiciário como limite ao jogo político, caso o Supremo Tribunal Federal torne a se guiar pela intencionalidade exclusiva ao Direito. A propósito, caso se recorde que o mínimo axiológico da comunidade se expressa na dignidade humana e nos direitos fundamentais, o instituto 
em questão pode revelar-se, inclusive, como um grande instrumento de concretização dos valores estruturantes da sociedade brasileira.

\subsection{DA HERMENÊUTICA (NECESSÁRIA) DOS VERBETES SUMULARES}

Assim como os assentos portugueses, as súmulas vinculantes foram instituídas a fim de se levar ao plano jurisprudencial aquela forma de vinculação (do positivismo legalista) que não se conseguiu realizar no âmbito legislativo, em razão da essência problemática do Direito.

Tomando o silogismo e o método dedutivo como instrumentos, o positivismo legalista pressupõe a aplicação ao caso concreto de uma normatividade preexistente no texto legal, sendo essa normatividade abstraída dos casos particulares, já que ela é encontrada no campo metafísico (na imanência do ser, do texto). Desse modo, as súmulas vinculantes serviriam justamente como expressão dessa norma preexistente no texto da lei, para que, a partir de sua edição, não houvesse mais dúvidas sobre o sentido do dispositivo legal.

Contudo, essa concepção legalista apresenta dois erros fundamentais: primeiro, confunde texto com norma; e, ainda, ignora a problematicidade que é ínsita à realização do Direito.

Tanto as leis quanto as súmulas vinculantes não são, em si, normas, mas sim textos normativos, os quais, portanto, sempre admitem interpretação pelo julgador. Sem dúvida, essa constatação traz perplexidades à própria intencionalidade original das súmulas, pois, pensadas para resolverem, em definitivo, divergências interpretativas, elas próprias, por admitirem interpretação, abrem espaço para dúvidas sobre seu sentido (ABBOUD, 2009).

Embora as leis e as súmulas vinculantes se tratem de importantes pontos de partida para se determinar uma solução jurídica, a norma é produzida tão somente a partir do caso concreto e da problematização que ele permite ao ser confrontado com o ordenamento jurídico existente (ABBOUD, 2009). Por isso, não basta a mera subsunção do fato à norma (rectius, ao texto normativo), por não existir sentido que seja imanente a um texto.

Contudo, seria incorreto pensar que a problematização do caso concreto parte do zero, pois o sistema jurídico (as leis e os demais dispositivos) já carrega consigo uma intenção normativa que se refere ao caso-problema, podendo, inclusive, já pressupor um critério normativo ou um princípio jurídico para se aplicar no julgamento (NEVES, 2014).

Não obstante, a unidade do sistema jurídico não se fecha no quadro de problemas e soluções nele já previstos, pois, visando a uma unidade histórico-dialética, esse sistema possui uma abertura que lhe permite adaptar-se às mudanças histórico-sociais quando do enfretamento de novos problemas ou da busca de novas respostas a problemas já conhecidos (NEVES, 2014).

Nesse processo dialético de contínua (re)construção da unidade do Direito, não se pode perder de vista que a norma em si não se encontra nos textos existentes - os quais nem por isso deixam de carregar consigo uma intencionalidade normativa -, sendo, em vez disso, produto da busca do sentido histórico-concreto do texto. Nesse ponto, é de se ressaltar que "[...] não há manifestação jurídica que não seja, desde sempre, interpretativa" (STRECK; ABBOUD, 2015, p. 126-127) e, portanto, relacionada a determinado caso concreto, sendo 
essa nova visão do Direito fruto da hermenêutica filosófica (ABBOUD, 2009).

Nela, compreensão, interpretação e aplicação passam a constituir um único momento - qual seja, a própria compreensão - (GADAMER, 1997), o que afasta por completo a possibilidade de se buscar o sentido de um texto de forma apriorística. Nesse sentir, Hans-Georg Gadamer ressalta que, quanto a um texto, "[...] se se quiser compreendê-lo adequadamente, isto é, de acordo com as pretensões que o mesmo apresenta, tem de ser compreendido em cada instante, isto é, em cada situação concreta de uma maneira nova e distinta. Aqui, compreender é sempre também aplicar." (GADAMER, 1997, p. 461).

Considerando que "A tarefa da interpretação consiste em concretizar a lei em cada caso, isto é, em sua aplicação" (GADAMER, 1997, p. 489, grifo do autor), é inviável se sustentar o velho método lógico-subsuntivo não apenas para as leis, como também para as súmulas vinculantes, ainda que isso implique ruptura com a teleologia original desse instituto. Afinal, a concretização casuística do Direito se faz imperativa.

Assim procedendo, também estará superado o problema correlato ao silogismo, qual seja, a garantia da igualdade meramente formal. Ora, conscientes dos reclamos de justiça - que, como visto, guardam direta relação com a igualdade material e o atendimento às particularidades dos casos concretos -, a hermenêutica filosófica se propõe justamente a olhar ao particular, ao histórico, e não a abstrações, o que exige do juiz a aplicação do texto normativo atento às peculiaridades do caso, retirando-o da confortável praxe de simplesmente subsumir fatos a normas, como se o sentido do texto lhe fosse imanente.

Não obstante, em cada interpretação do texto normativo, é importante reconstruir "[...] interpretativamente a história institucional do instituto ou dispositivo em comento" (STRECK; ABBOUD, 2015, p. 128), pois, assim como nos precedentes, será possível saber se a intencionalidade normativa daquele texto é efetivamente voltado ao caso sub examine.

Diante de tais consideraçóes, é cabível afirmar que as súmulas vinculantes, como mais uma forma de disposição legislativa, compatibilizam-se com as exigências de realização do Direito, à medida que passarem a servir como ponto de partida para a solução de casos "idênticos" com aqueles que as ensejaram, pela extração de um critério jurídico comum, e não mais como a norma em si, na qual se possam subsumir uma generalidade de casos cujo fundo fático se represente em um mínimo comum desprovido das próprias peculiaridades.

\subsection{DO CONTROLE DE CONSTITUCIONALIDADE DOS ENUNCIADOS SUMULARES}

Enfim, as súmulas vinculantes, como prescrições de natureza legislativa, também devem estar sujeitas ao controle de constitucionalidade, por mais paradoxal que possa parecer a possibilidade de o Supremo Tribunal Federal - guardião da Constituição (art. 102, caput, CF) - editar súmulas inconstitucionais.

Parece decorrer logicamente da "natureza de lei" das súmulas vinculantes a possibilidade de seu controle de constitucionalidade. Com efeito, Nelson Nery Junior e Rosa Nery, 
levando em consideração essa natureza e o fato de os enunciados sumulares vincularem o Poder Judiciário e o Executivo, asseveram tanto a possibilidade de controle difuso quanto a de controle concentrado de constitucionalidade de tais enunciados (NERY JUNIOR; NERY, 2014).

Todavia, em sentido diverso sobre o controle concentrado, André Ramos Tavares entende descabido o ajuizamento de Ação Direta de Inconstitucionalidade (ADI), bem como de Arguição de Descumprimento de Preceito Fundamental (ADPF) contra súmula vinculante, por existirem mecanismos legais de revisão e cancelamento dos enunciados (TAVARES, 2009). ${ }^{15}$

Contudo, não parece ser esse o raciocínio correto. Isso porque o art. $6^{\circ}$ da Lei $n^{\circ}$ 11.417/06 veda expressamente a suspensão dos processos em que se discuta matéria cujo enunciado esteja em processo de revisão ou cancelamento perante o STF, ao passo que a ADI admite medida cautelar (cf. art. 102, I, "p", da CF). Quer dizer, enquanto o Supremo Tribunal Federal não se dignificar a efetivamente revisar ou cancelar enunciado sumular inconstitucional, ele continuará a ser de observância obrigatória, sob pena de cassação da decisão judicial ou anulação do ato administrativo.

Ademais, o fato de uma lei poder ser revogada a qualquer tempo não é fundamento suficiente para afastar a possibilidade do judicial review, já que, enquanto estiver produzindo efeitos (ou seja, enquanto estiver vigendo), a lei estará sujeita à análise de sua compatibilidade com a Constituição Federal, até que ocorra sua revogação - e isso se ela ocorrer.

Em torno do controle difuso de constitucionalidade, mostra-se mais pacífica sua possibilidade dentro da doutrina. ${ }^{16}$ Em seu favor, concorre, segundo Georges Abboud, o fato de o judicial control ser um direito fundamental, a previsão do direito de ação no art. $5^{\circ}, \mathrm{XXXV}$, da Constituição Federal - que assegura a inafastabilidade da jurisdição em casos de lesão ou ameaça de lesão a direito -, bem como o próprio princípio da independência judicial (ABBOUD, 2009).

Com efeito, o controle de constitucionalidade permite a harmonia entre as súmulas vinculantes e o princípio da independência judicial, na medida em que, por meio dele, é possível quebrar com o caráter autoritário, hierarquizado e burocrático que a observância cega das súmulas geraria, permitindo, assim, a preservação do Estado de Direito (em que os juízes concorrem para a promoção da ordem jurídica) (STRECK; ABBOUD, 2015).

Frise-se que, como prescrições legislativas, os juízes devem observar as súmulas vinculantes, assim como as leis, pois ambas se tratam, a seu modo, de expressões da intencionalidade ao Direito emanadas de órgãos constitucionalmente legitimados para tanto.

Contudo, caso contrariem princípios constitucionais, aos juízes deve ser possível declarar a inconstitucionalidade dos enunciados sumulares, pois, se os magistrados podem afastar uma lei (e até mesmo uma Emenda Constitucional), com maior razão, poderão rejeitar a aplicação de uma súmula vinculante, a fim de promover, no caso concreto, um julgamento justo, com base nos valores constitucionais. 


\section{CONSIDERAÇÕES FINAIS}

Em seus termos originais, as súmulas vinculantes causam perplexidades ao ordenamento jurídico brasileiro, pois, a exemplo dos assentos portugueses, elas se tratam de enunciados de natureza legislativa, que, ao pretenderem ser critérios jurídicos apriorísticos, exigem sua aplicação lógico-dedutiva (mera subsunção do fato à norma).

Diante disso, não tardou para se constatar o impasse criado ao princípio da separação dos poderes, que, embora não exija uma "separação" absoluta, continua a informar a inacumulabilidade das funções jurisdicionais e legislativas em um mesmo titular do poder estatal. Isso porque o Judiciário - titular da jurisdição - deve orientar-se pela realização do Direito - ou seja, o juízo jurisdicional deve pautar-se na intencionalidade ao Direito, ao todo axiológico comunitário que ele representa - e não pela política - vale dizer, pelo decisionismo entre os valores comunitários em razão de opções partidário-ideológicas, o qual é próprio do Poder Legislativo, órgão no qual é propício assim agir. Com as súmulas vinculantes, o Judiciário brasileiro corre o risco de se afastar de sua função de contrapoder, em razão de sua entrada no jogo político, estando fragilizado, portanto, o Estado de Direito que pressupõe a limitação do poder pelo Direito.

Ainda, analisou-se o entrave que as súmulas vinculantes representam à realização da unidade integrante dos valores comunitários; pois, ao pressuporem o silogismo - ou seja, uma aplicação padrão de um principium jurídico, sem se atentar às particularidades do caso -, as súmulas promovem apenas a igualdade no sentido formal, o que, todavia, encontra-se em descompasso com os reclamos hodiernos de justiça e igualdade material.

Também se enfrentou o problema gerado pelas súmulas vinculantes à independência judicial, sendo de aplicabilidade inflexível, as súmulas se revelam um instrumento autoritário e burocrático, que, desse modo, impede a contribuição de todos os magistrados para a realização do Direito, em favor de uma lógica de mera redução do volume de processos, principalmente nas instâncias extraordinárias.

Não obstante as perplexidades apontadas, o instituto em apreço se apresenta, ao menos formalmente constitucional, visto que sua inserção na Constituição Federal respeitou o devido processo legislativo. Em torno da matéria, a legitimidade do instituto é colocada à prova, mas, ainda sim, é possível as súmulas vinculantes serem (re)inseridas em uma roupagem compatível com o Estado de Direito.

Nesse sentido, aferiu-se que o exercício da função legislativa não implica, em si, o emprego da índole política, sendo, assim, possível ao STF se orientar exclusivamente pelo Direito quando da edição das súmulas vinculantes.

Por se tratarem de textos normativos, tais súmulas também se mostram passíveis de interpretação, assim como as leis, motivo pelo qual, sob a orientação da hermenêutica filosófica, é possível (e devido) ao juiz se valer dos enunciados sumulares - e de sua intencionalidade normativa - para problematizar os casos concretos, a fim de buscar a solução mais justa em cada caso. Com isso, a contribuição dos magistrados é levada em consideração, pois não anu- 
lado seu dever de prudência ("juízo") para se decidir a concretude de uma situação sub judice. Considerando ainda a natureza legislativa do instituto, também se defendeu a possibilidade de submetê-lo ao controle de constitucionalidade concreto e difuso, pois, se nem mesmo as leis vinculam em absoluto, não haveria razão para as súmulas assim o fazerem. Ademais, estando os juízes sob o império do Direito - no qual a Constituição ocupa posição de destaque -, e não de um Tribunal - ainda que Supremo -, deve sempre haver a possibilidade de os magistrados testarem a compatibilidade de um texto normativo às normas constitucionais. Desse modo, o autoritarismo ínsito à natureza primeva das súmulas seria extirpado, reafirmando-se aos juízes o seu papel de promoverem exclusivamente o Direito.

Diante de todo o exposto, é possível concluir pela legitimidade das súmulas vinculantes, não apenas porque elas são formalmente constitucionais, mas também por se revelarem compatíveis com o ordenamento jurídico brasileiro, na medida em que deixam alguns de seus propósitos originais.

\title{
ON THE LEGITIMACY OF BINDING PRECEDENTS (SÚMULAS VINCULANTES)
}

\begin{abstract}
This article deals with the compatibility of the institute of binding precedents (sumulas vinculantes) with the principles of separation of powers and judicial independence, and analyzes how its application impacts the postulates of material equality and justice. The debate surrounding the legitimacy of such institute is necessary in view of the markedly pragmatic character that guided its creation through Constitutional Amendment n. 45/2004. Initially discussing the "legislative nature" of binding precedents (súmulas vinculantes), the article approaches the impasses that its original purposes generate in the Brazilian legal system, considering the previously indicated principles and postulates. This research, however, aims at analyzing the possible solutions to the aforementioned problems. Thus, the hypothesis put forth is that binding precedents may prove to be legitimate, even if some of their initial terms have to be revised and other major debates have to be addressed.
\end{abstract}

Keywords: Binding precedents (súmulas vinculantes). Legitimacy. Brazilian legal system.

\section{LA LEGITIMIDAD DE LAS INTERPRETACTIONES VINCULANTES}

\section{RESUMEN}

Este artículo trata de la compatibilidad del instituto de las interpretaciones vinculantes con los principios de la separación de poderes y de la independencia judicial y analiza la forma como su metodología de aplicación impacta los postulados de igualdad material y de 
justicia. El debate acerca de la legitimidad de ese instituto es necesario, teniendo en cuenta el carácter marcadamente pragmático que orientó su creación por medio de la Enmienda Constitucional n. 45/2004. Con la constatación inicial de la "naturaleza legislativa" de las interpretaciones vinculantes, se abordan los impases que sus propósitos originales generan en el ordenamiento jurídico brasileño, considerando los principios y postulados anteriormente informados. Sin embargo, esta investigación se propone a analizar las posibles soluciones a los problemas apuntados. Así, la hipótesis acá defendida es de que las interpretaciones vinculantes pueden revelarse legítimas, aunque para tanto algunos de sus términos iniciales tengan de ser revisados, y que otros grandes debates tengan que ser enfrentados.

Palabras-clave: Interpretación Vinculante. Legitimidad. Ordenamiento jurídico brasileño.

1 Sobre a similaridade entre súmulas vinculantes e assentos portugueses, cf. Abboud (2008).

2 A propósito das normas jurídicas, Castanheira Neves esclarece que "norma jurídica" não é apenas a "lei" (em sentido estrito, ou seja, as normas emanadas do Poder Legislativo a partir do processo constitucionalmente previsto), pois também existem as normas jurídicas consuetudinárias, as de origem jurisprudencial, as emergentes da autonomia privada, bem como as oriundas da doutrina (NEVES, 2014, p. 283). Mais adiante, ele ressalva que nem todas elas possuem caráter prescritivo, como é o caso das doutrinárias e das correntes jurisprudenciais (NEVES, 2014, p. 299).

3 Segundo Paulo Nader, "Fontes formais são os meios de expressão do Direito, as formas pelas quais as normas jurídicas se exteriorizam, tornam-se conhecidas. Para que um processo jurídico constitua fonte formal é necessário que tenha o poder de criar o Direito." (NADER, 2007, p. 142). In casu, as súmulas vinculantes veiculam normas jurídicas capazes de inovar o ordenamento jurídico, motivo pelo qual é de se reconhecer seu status de fonte formal do Direito.

4 Art. $5^{\circ}$. Revogada ou modificada a lei em que se fundou a edição de enunciado de súmula vinculante, o Supremo Tribunal Federal, de ofício ou por provocação, procederá à sua revisão ou cancelamento, conforme o caso.

5 Também afirmando a natureza de disposição legislativa das súmulas vinculantes, cf. Nery Junior e Nery (2014, p. 740-741).

6 Não se olvida que muitos autores ainda se valem do Poder Legislativo - ou do poder político em sentido estrito - para conceituar a "lei". Nesse sentido, cf. nota ${ }^{\circ} 7$, infra.

7 Nesse sentido "tradicional", Paulo Nader conceitua a "lei" como "[...] o preceito comum e obrigatório, emanado do Poder Legislativo, no âmbito de sua competência." (NADER, 2007, p. 148, grifo do autor). Paulo Nader ainda atribui caracteres substanciais e formais às leis (stricto sensu). Em torno dos caracteres substanciais, aponta a "generalidade, abstratividade, bilateralidade, imperatividade, coercibilidade". No tocante aos caracteres formais, assevera que a lei deve ser "escrita, emanada do Poder Legislativo em processo de formação regular, promulgada e publicada." (Ibid., loc. cit.). Como se observa, apenas a nota "emanada do Poder Legislativo" não se verifica nas súmulas vinculantes, o que corrobora a tese de "natureza legislativa" desse instituto, ao menos no aspecto material.

8 Esse sistema foi desenvolvido pelos norte-americanos com base na doutrina de Montesquieu e é conhecido em português como "sistema de freios e contrapesos" (MALUF, 2007, p. 210-211).

9 Conforme Castanheira Neves, a política em sentido estrito, própria do Legislativo, significa "[...] a actividade de direcção e conformação social que actua uma comprometida ('partidária') teleologia ideológica e a distinguir de outras específicas actividades sociais, as actividades específicas da economia, da cultura, v. g. do direito, etc." (NEVES, 2014, p. 430).

10 Com certa reserva, Mancuso (2013, p. 175) também aponta a necessidade de divergência jurisprudencial para a concretização do Direito.

11 Artigo 115 (Actos normativos) [...] 5 - Nenhuma lei pode criar outras categorias de actos legislativos ou conferir a actos de outra natureza o poder de, com eficácia externa, interpretar, integrar, modificar, suspender ou revogar qualquer dos seus preceitos. Cf. Portugal (1976). Esse dispositivo (artigo e seus números) foi acrescido pelo artigo $93^{\circ}$ da $1^{\text {a }}$ Revisão Constitucional - Lei Constitucional n ${ }^{\circ} 1 / 82$, sendo renumerado para artigo $112^{\circ}$ pela $4^{a}$ Revisão Constitucional - Lei Complementar $n^{\circ} 1 / 97$ (v. artigo $74^{\circ}, \mathrm{n}^{\circ} 1$ ). Atualmente, o dispositivo citado se encontra previsto no artigo $112^{\circ}, \mathrm{n}^{\circ} 5$ ( $\mathrm{cf}$. as Leis Constitucionais citadas no sítio eletrônico do Tribunal Constitucional de Portugal. Disponível em: <http://www.tribunalconstitucional.pt/tc/crp-revisoes.html >. Acesso em: 25 out. 2016). 
12 Segundo Ávila (2011, p. 30-31), "Pelo exame dos dispositivos que garantem a legalidade, a irretroatividade e a anterioridade chega-se ao princípio da segurança jurídica."

13 Os assentos portugueses eram regulados pelo artigo 769 do Código de Processo Civil de 1961, sendo previstos como fonte do direito no mencionado artigo $2^{\circ}$ do Código Civil de 1966.

14 No caso do Brasil, a crítica se aplica com a agravante de que aqui não há, como em Portugal, um Tribunal Constitucional, que, em tese, pode ser provocado em casos de inconstitucionalidade, caso admitido esse controle, ou seja, é possível conceber em Portugal um julgamento imparcial sobre os assentos editados pelo Supremo Tribunal de Justiça português, ao passo que, no Brasil, o controle (em última "instância") das súmulas vinculantes se daria, afinal de contas, pelo próprio órgão que as edita: o STF.

15 Embora não tenha tido a oportunidade de se manifestar especificamente sobre as súmulas vinculantes, o Supremo Tribunal Federal já entendeu pelo descabimento do controle concentrado de constitucionalidade contra súmulas - "simples", no caso (MANCUSO, 2013. p. 440).

16 Cf. Mancuso (2013, p. 440-441); Nery Junior e Nery (2014, p. 742); Streck e Abboud (2015, p. 139-140).

\section{REFERÊNCIAS}

ABBOUD, Georges. Sentenças interpretativas, coisa julgada e súmula vinculante: alcance e limites dos efeitos vinculante e erga omnes na jurisdição constitucional. 2009. 309 f. Dissertação (Mestrado em Direitos Difusos e Coletivos) - Pontifícia Universidade Católica de São Paulo, São Paulo, 2009. Disponível em: <http://www.dominiopublico.gov.br/download/ teste/arqs/cp113238.pdf>. Acesso em: 14 set. 2016.

. Súmula vinculante versus precedentes: notas para evitar alguns enganos. Revista de Processo, São Paulo, v. 33, n. 165, p. 218-230, nov. 2008.

ÁVILA, Humberto. Teoria dos princípios: da definição à aplicação dos princípios jurídicos. 12. ed. São Paulo: Malheiros, 2011.

CLÈVE, Clèmerson Merlin. A lei no estado contemporâneo. Cadernos de Direito Constitucional e Ciência Política, São Paulo, v. 1, n. 21, p. 124-137, 1997.

CÔRTES, Osmar Mendes Paixão. Súmula vinculante e segurança jurídica. São Paulo: Revista dos Tribunais, 2008.

GADAMER, Hans-Georg. Verdade e método. Tradução de Flávio Paulo Meurer. Petrópolis: Vozes, 1997.

LEAL, Vitor Nunes. Atualidades do Supremo Tribunal. Revista de Direito Administrativo, Rio de Janeiro, v. 78, p. 453-459, out./dez. 1964. Disponível em: < http://bibliotecadigital. fgv.br/ojs/index.php/rda/article/view/26723>. Acesso em: 10 out. 2016.

. Passado e presente da súmula do STF. Revista de Direito Administrativo, Rio de Janeiro, n. 145, p. 1-20, jul./set. 1981. Disponível em: < http://bibliotecadigital.fgv.br/ojs/ index.php/rda/article/view/43387> . Acesso em: 10 out. 2016.

MACHADO, Fábio Cardoso. Da uniformização jurídico-decisória por vinculação às súmulas de jurisprudência: objeções de ordem metodológica, sócio-cultural e político-jurídica. Revista de Processo, São Paulo, v. 30, n. 124, p. 123-148, jun. 2005. 
MALUF, Sahid. Teoria geral do estado. 27. ed. Atualização de Miguel Alfredo Maluf Neto. São Paulo: Saraiva, 2007.

MANCUSO, Rodolfo de Camargo. Divergência jurisprudencial e súmula vinculante. 5 . ed. São Paulo: Revista dos Tribunais, 2013.

NADER, Paulo. Introdução ao estudo do direito. 28. ed. Rio de Janeiro: Forense, 2007.

NERY JUNIOR, Nelson; NERY, Rosa Maria de Andrade. Constituição federal comentada e legislação constitucional. 5. ed. São Paulo: Revista dos Tribunais, 2014.

NEVES, António Castanheira. O instituto dos “assentos” e a função jurídica dos supremos tribunais. Coimbra: Coimbra Editora, 2014.

PORTUGAL. Assembleia Constituinte. Constituição da República Portuguesa. Lisboa, 2 de abril de 1976. Disponível em: <http:/www.tribunalconstitucional.pt/tc/crp.html>. Acesso em: 25 out. 2016.

. Tribunal Constitucional. Acórdão nº 810/1993. Lisboa, 7 de dezembro de 1993. Disponível em: < http://www.tribunalconstitucional.pt/tc/acordaos/19930810.html >. Acesso em: 25 out. 2016.

SARLET, Ingo Wolfgang et al. Curso de direito constitucional. 2. ed. São Paulo: Revista dos Tribunais, 2013.

SORMANI, Alexandre; SANTANDER, Nelson Luis. Súmula vinculante: um estudo à luz da emenda constitucional 45, de 08.12.2004. 2. ed. Curitiba: Juruá, 2009.

STRECK, Lenio Luiz; ABBOUD, Georges. O que é isto: o precedente judicial e as súmulas vinculantes? 3. ed. Porto Alegre: Livraria do Advogado, 2015.

TAVARES, André Ramos. Nova lei da súmula vinculante: estudos e comentários à Lei 11.417, de 19.12.2006. 3. ed. São Paulo: Método, 2009.

TOFFOLI, Vitor. Desafios para tutela do direito autoral na era digital, relações com o direito à educação e o acesso à Justiça, como meio de efetivação desses direitos da personalidade: conflitos e possíveis soluções conciliatórias. 2013. 208 f. Dissertação (Mestrado em Ciências Jurídicas) - Centro Universitário de Maringá, Maringá, 2013. Disponível em: $<$ https://vitortoffoli.files.wordpress.com/2013/05/dissertac3a7c3a3o-versc3a3o-wordpress. pdf>. Acesso em: 14 set. 2016.

Submetido: 31 mar. 2017

Aprovado: 7 jun. 2017 